COMMENTARY ON COVID-19 AND THE FoOd SYSTEM

\title{
Community Capitals Policing merges food economy and public safety, repairing decades of harm
}

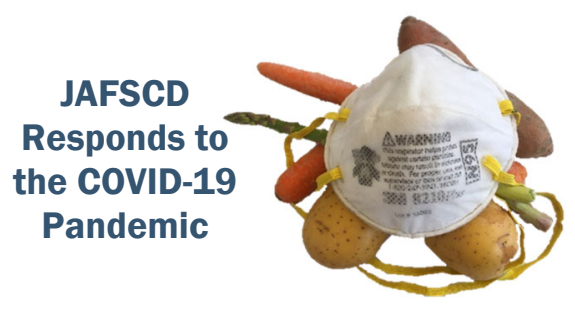

\author{
Captain Martin J. Neideffer* \\ Alameda County Sheriff's Office
}

Submitted September 30, 2020 / Published online December 9, 2020

Citation: Neideffer, M. J. (2020). Community Capitals Policing merges food economy and public safety, repairing decades of harm. Journal of Agriculture, Food Systems, and

Community Development, 10(1), 247-250. https://doi.org/10.5304/jafscd.2020.101.031

Copyright (C) 2020 by the Author. Published by the Lyson Center for Civic Agriculture and Food Systems. Open access under CC-BY license.

\begin{abstract}
A local, circular food economy like the one we are building in Alameda County, California, will not A only alleviate food insecurity, create jobs, and improve the environment, it is also a centerpiece of our 15-year-long effort to strengthen social cohesion, repair trust, and improve public safety through a revolutionary new approach to policing.

More than 15 years ago, the Alameda County Sheriffs Office launched a new brand of public safety, called Community Capitals Policing, ${ }^{1}$ in Ashland and Cherryland, two unincorporated communities just south of Oakland, California. These communities have experienced disproportionate levels of crime, poverty, disinvestment, disease, unemployment, and blight since the late 1970s.

Our work, based on the community capitals framework (Fey, Bregendahl, \& Flora, 2006), is taking a systems-level approach to repair the harm done to the community over decades of systemic racism and neglect. The work is informed by a seven-year project called Food Dignity, funded by a US $\$ 5$ million grant from the U.S. Department of Agriculture. Through the Food Dignity project, leaders of five community-based food justice organizations and academics from three universities sought to strengthen local food systems and enable more people to not only choose what they eat, but also how their food is produced and processed and what role they wanted to play in the food system. More than three dozen researchers and activists from diverse backgrounds and communities worked on the project, including sworn and civilian employees of the Alameda County Sheriffs Office. In 2018, the project collaborators
\end{abstract}

* Captain Martin J. Neideffer, Alameda County Sheriffs Office, mjneideffer@acgov.org

${ }^{1}$ See more about Community Capitals Policing at https://drive.google.com/file/d/1Q06HRbTTloOkztzVZfwBXIlFIbyT-Ccx/view 
published a full special issue of the Journal of Agriculture, Food Systems, and Community Development. ${ }^{2}$

We carry out our work through a seamless partnership with the nonprofit Deputy Sheriffs' Activities League, ${ }^{3}$ and our effort is fueled by direct community input. We also receive support from dozens of county agencies, nonprofit organizations, and foundations.

Our successes - which are many — include launching a social enterprise, called Dig Deep Farms, with more than 8 acres ( 3.2 hectares) of productive urban farmland spread across four farms where urban farmers use permaculture design to grow no-pesticide fruits and vegetables, making healthy food available in neighborhoods where fast food and liquor stores predominate. Dig Deep Farms works with people reentering the community from incarceration, offering them permaculture certification, work experience, and paid internships.

Dig Deep Farms features a 3,300-square-foot (307-square-meter) Food Hub, a community-based food packaging and distribution center with a commercial kitchen where local food entrepreneurs can incubate and grow their businesses. The Food Hub opened in January 2020 and represents a US $\$ 3$ million renovation of an existing structure on county-owned land funded by the Deputy Sheriffs' Activities League through a US $\$ 1.2$ million loan and US $\$ 1.8$ million in grant support.

Together, these efforts have formed the basis of an emerging circular food economy that is replacing unhealthy, industrially grown food with fresh, regeneratively grown fruits and vegetables, while also eliminating waste, reducing greenhouse gasses, and repairing the soil and the environment.

The circular food economy we envision redefines growth by focusing on society-wide benefits instead of corporate profits; eliminates waste and pollution; works to regenerate natural systems, like soil, water, and air; and creates good jobs for local residents, while also supporting small farms and local food businesses.

\section{Hunger, Public Safety, and the COVID-19 Pandemic}

An estimated $12.2 \%$ of Alameda County's population-about 200,000 people--do not have enough food. These numbers are skyrocketing during the COVID-19 crisis as more and more breadwinners lose their jobs and families scramble to make ends meet. Simply put, we are in the midst of a full-scale hunger crisis.

When COVID-19 struck, the Deputy Sheriffs Activities League and Dig Deep Farms sprang into action and began distributing free groceries and fresh produce to food-insecure families. With support from a local foundation, we were able to provide US $\$ 15,000$ grants to local food businesses to prepare healthy meals for seniors and vulnerable populations. Hundreds of cars line up on Fridays to pick up free groceries, and 18 local food businesses received grants that helped them keep their doors open and keep their workers on the job. We also expanded our partnership with the county office of probation to arrange for the delivery of groceries to seniors and vulnerable populations as part of our effort to provide career pathways for those coming through periods of incarceration to prevent recidivism and further social cohesion.

As of late August 2020, we had distributed nearly 40,000 bags of groceries and delivered more than 20,000 prepared meals to those in need.

Despite these challenging times, we have continued to push forward on a comprehensive solution to building a new local food economy — one that focuses on equity, sustainability, and health. Our approach is documented in a new report, "Alameda County Circular Economy for Food" (Priebe, 2020), which provides an analysis of our current food system, a detailed financial model, and recommendations to

${ }^{2}$ See the special issue (summer 2018) at https://www.foodsystemsjournal.org/index.php/fsj/issue/view/food-dignity-issue

3 https://www.acdsal.org/ 
guide the development of a new, regenerative, local food economy.

The good news is that many elements of the circular food economy have already been built as part of our Community Capitals Policing initiative. The challenge, however, is that no part of the circular food economy can be understood in isolation. The circular food economy will require systems-level change, but systems-level change is difficult because it requires people to get out of their silos and work together on a shared vision. The "Alameda County Circular Economy for Food" report provides a precise vision along with a step-by-step plan to bring that vision to fruition.

When you line up the work we are doing to grow a local, circular food economy, along with the accomplishments we have achieved through Community Capitals Policing (providing free recreational activities for kids, hosting community events that enliven public spaces, building soccer parks and gyms where there were none, creating a municipal advisory council to give local community members a voice, supporting public art, providing behavioral health services, and much more), and then incorporate the sense of collective efficacy and engagement we have engendered with the sworn elements of the sheriff's office, you begin to see a brighter future not only for the community, but also for the institution of policing.

Viewing these systems through the lens of policing — and having the sheriff's office spearhead the effort to drive systems change-is leading to fresh, productive solutions that are producing tangible results for the individuals, families, and communities who have suffered most from the racist policies of the past.

\section{References}

Fey, S., Bregendahl, C., \& Flora, C. (2006). The measurement of community capitals through research. Online Journal of Rural Research \& Policy, 1(1), Art. 1. https://doi.org/10.4148/ojrrp.v1i1.29

Priebe, M. B. (2020). Alameda County circular economy for food: A pathway for growth. Oakland, CA: ALL IN Alameda County \& Alameda County Deputy Sheriffs' Activities League. Retrieved from https://drive.google.com/file/d/1r7Vek1Rx5Yz7p9bt04fQ7VzexMhGH2p/view 